\title{
細胞性製剤の設計 ·創製と細胞療法への展開
}

\author{
岡田直貴
}

\section{Design and Creation of Cytomedicine for Application to Cell Therapy \\ Naoki OKADA \\ Department of Biopharmaceutics, Kyoto Pharmaceutical University, 5 Nakauchi-cho, Misasagi, Yamashina-ku, Kyoto 607-8414, Japan}

(Received April 28, 2005)

\begin{abstract}
Cells, which are the basic unit of life, are the most intelligent particles on earth. Recent advances in life science research encourage the development of cell therapy utilizing specialized functions of highly differentiated cells, the selfrenewal and differentiation abilities of stem cells, and signal networks among various types of cells. Although cell therapy including ex vivo gene therapy, cellular immunotherapy, and regenerative therapy is expected to become the next generation of medical care for intractable disorders, the establishment of technology to prepare cells as medical supplies, namely, cytomedicine, is essential for the assurance of efficacy and safety in cell therapy. This review introduces our approach to the design and creation of cytomedicine for application to cell therapy against diabetes mellitus and cancer.
\end{abstract}

Key words_ cytomedicine; cell therapy; APA-microencapsulation; dendritic cell-based immunotherapy; cell delivery systems

\section{1.はじめに}

生命体の基本単位である細胞は地球上で最もイン テリジェントな粒子であり，機能的・形態的に異な る様々な細胞の有機的連関によつて生命体の恒常性 は形成維持されている。近年の生命科学の目覚しい 進展は, 細胞間の協調的な増殖 - 分化制御機構や数 多くの情報伝達ネットワークの詳細を解明し, 細胞 が本来的に有する種々の機能を利用した次世代医療 システム，すなわち細胞療法の開発を推進する原動 力となった。例えば免疫応答の制御機構に関する知 見は，各免疫細胞サブセットの機能・役割を特定す るとともに，それらの投与による免疫反応調節に基 づいて癌や免疫疾患の治療を達成しようとする細胞 免疫療法へと展開された。 また，昨今注目を集めて いる再生医療の発展が, 胚性幹細胞・組織幹細胞の 発見とそれらの特性解析に大きく依存していること は言うまでもない。一方, 薬剤学的観点から細胞療 法を眺めてみると，細胞を医薬品化するための創剂

京都薬科大学（干607-8414 京都市山科区御陵中内町 5 番地)

e-mail: okada@mb.kyoto-phu.ac.jp

本総説は, 平成 17 年度日本薬学会奨励賞の受賞を記念

して記述したものである.
テクノロジーの確立が細胞療法の有効性並びに安全 性を保証する上で不可欠であることに気付かされ る.また，機能粒子素材・製剂素材として捉えた細 胞の機能増強や細胞への新たな機能付与を行うため には，遺伝子導入法など細胞への物質送達技術（創 薬テクノロジー）の開発・最適化も必要とされる.

本稿では，様々な分野の基盤技術に立脚した細胞 性製剂の設計・創製に関する筆者らの取り組みを紹 介するとともに，創製した細胞性製剂による細胞療 法（次世代型薬物療法・ワクチン療法）の有用性及 び将来性について概説する.

\section{2. 細胞の DDS（Drug Delivery System）的機能}

\section{を基盤とする細胞療法}

薬物治療の有効性, 安全性及び信頼性に高い保証 を与えると言う観点から, リポソームやマイクロカ プセルあるいはナノパーティクル等を利用すること で薬物徐放性等の機能を付与した DDS 製剤の開発 が盛んに行われている。一方で, 生命体を構成する 細胞は厳密な時間的・空間的制御のもと, 生体内外 の刺激に応答してホルモンやサイトカインを始めと する生理活性物質を合成・分泌し, 恒常性維持に最 適な機能を発揮している。生理活性物質を薬物に見 立てた場合，これはまさに「必要な時に，必要な場 
所で，必要な量の薬物を作用させる」ことを目的と した DDS を具現化したものであり，機能性・合理 性と言う面から眺めると細胞は最も優れた DDS 粒 子と言えよう。すなわち，内外環境の変化を察知 （センサー機能）し，この変化に応答して生理活性 物質を生合成・分泌（徐放機能）する細胞の能力を 利用した細胞性製剂こそ究極の徐放化 DDS 製剂と なり得る.

しかし，生体は生物学的な自己を識別する免疫系 を高度に進化させ生体防御の中心的システムとして いるため，同種異系（allogeneic）あるいは異種 (xenogeneic) の機能性細胞を生体に直接投与する と，たちまちホストの免疫系により細胞性製剤は拒 絶され短期間でその機能を失うことは必至である.

また，例え自己由来（autologous）細胞を利用した 場合においてさえ，遺伝子工学的・細胞工学的修飾 が施されたことによる抗原性発現の可能性は否定で きない。さらに，ホストと遺伝学的及び免疫学的に 近縁な樹立化細胞（cell line）を利用した場合には 腫瘍原性も大きな問題となる。したがって，生理活 性物質（薬）の徐放機能を有する細胞性製剂を安定 に機能させるためには，生体防御機構に不可欠な免 疫系に影響を与えることなく，生体内で非自己の機
能性細胞を長期間生存させると言う矛盾した問題を 解決しなければならず，その上で安全性をも考慮に 入れた粒子設計が要求される。

2-1. マイクロカプセル型細胞性製剤の設計・創 製本観点から筆者らは，半透性の高分子物質を 用いて機能性細胞を包括固定化し，物理的バリアー によって機能性細胞を宿主免疫系から隔離すること で，生体内で長期間に渡って生理活性物質を分泌す る細胞性製剤の開発が可能になると考えた（Fig. 1). 1-9) このストラテジーに応用する高分子担体 （マイクロビーズ，マイクロカプセル）は，内部に 封入した機能性細胞の生存・増殖・機能発現に不可 欠な酸素/二酸化炭素のガス交換や栄養物/老廃物の 透過を制限することなく，封入細胞が産生・分泌す る生理活性物質を外部へ自由に透過させ，封入細胞 の外部への漏出と宿主免疫細胞の内部への侵入をと もに遮断する機能を有していなければならない。さ らに，封入細胞への毒性・傷害性を示さず，生体内 で分解を受けることなく長期間安定に存在し，生体 適合性にも優れる等の条件を併せ持つ必要がある.

これらの条件を踏まえて筆者らは，アルギン酸と ポリリジンからなる APA マイクロカプセルが免疫 隔離能を付与した細胞性 DDS 製剤の設計・創製に

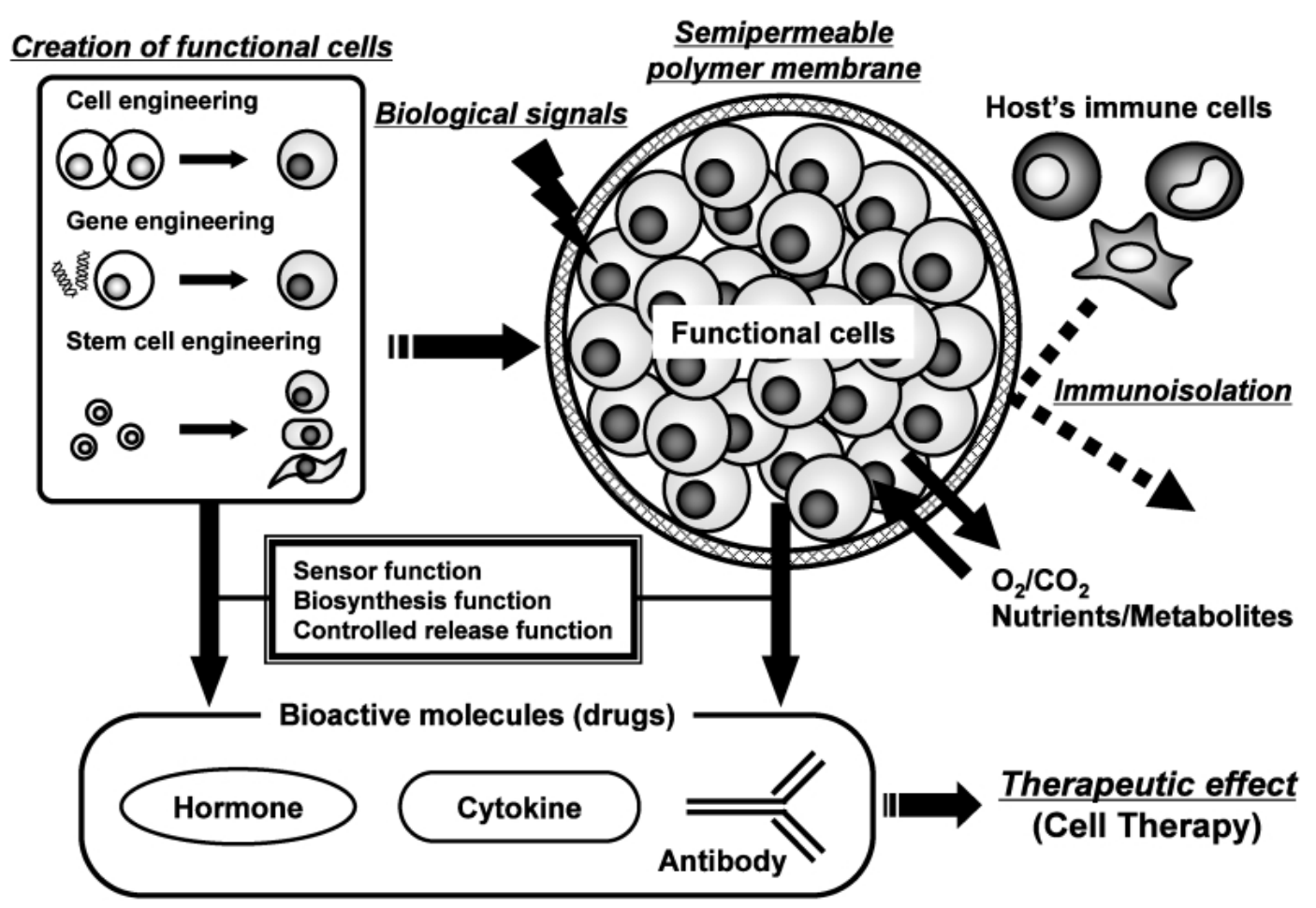

Fig. 1. A Conceptual Representation of Microencapsulation-based Cytomedicine to Apply DDS-function of Cells to Cell Therapy 
優れた高分子担体であることを見い出した. ${ }^{2-6)}$ ア ルギン酸はマンヌロン酸とグルロン酸からなるポリ アニオンであり，グルロン酸がカルシウムイオンや アルミニウムイオンなどの 2 価・3 価カチオンとキ レート結合することによりゲル化する。したがつ て，アルギン酸溶液を塩化カルシウム溶液に滴下す るだけで容易に固定化粒子が得られる。しかしなが ら，このアルギン酸マイクロビーズは培養液中ある いは生体内に存在する負荷電のリン酸イオン等によ りキレート結合が解かれるとゲルが崩壊してしま う。この欠点を克服したのが APA マイクロカプセ ルである，上記の方法で作製したアルギン酸マイク ロビーズをポリカチオンであるポリリジンの溶液に 浸漬すると, 静電的相互作用によりアルギン酸ゲル 表面に強固なアルギン酸ーポリリジン膜を形成す る.さらにこれをアルギン酸溶液に浸すことでポリ リジンの過剩な正荷電を中和し，アルギン酸ーポリ リジンーアルギン酸 (APA) の三層膜を形成させる. 最後に, 物質移動抵抗を低減させるとともに封入細 胞の増殖スペースを拡大するために, クエン酸溶液 に浸漬して内部のアルギン酸ゲル部分のキレート結 合を解離させて APA マイクロカプセルとする. APA マイクロカプセルの粒子径 - 膜厚 - 膜強度 物質透過性は, 調製に用いるポリリジンの分子量・ 濃度及びアルギン酸マイクロビーズをポリリジン溶 液とアルギン酸溶液に浸漬する回数によって調節す ることが可能であり，(1) 封入した機能性細胞が分 泌する生理活性物質（薬）の分子サイズ，(2) 封入 細胞と宿主との遺伝学的・免疫学的背景の組み合わ せにより要求される免疫隔離性，などの条件に併せ て最適化することができる。このうち Fig. 2 に示 すようなポリリジン（平均分子量：22400）溶液と アルギン酸溶液に 2 回ずつ浸漬して調製した APA マイクロカプセルについて, 封入細胞の生存性・生 体内安定性・生体適合性並びに免疫隔離能を評価し た.

APA マイクロカプセル内の細胞は in vitro 培養 系において長期間培養することが可能であり，封入 操作等による細胞傷害性は認められず，かつ生理活 性物質の分泌機能も正常に保持されていた. ${ }^{2,6)}$ また,

APA マイクロカプセルをマウスの腹腔内に投与し たところ，投与後 90 日目においても投与量のほぼ すべてを回収することが可能であり，それら APA
A

1)

2)
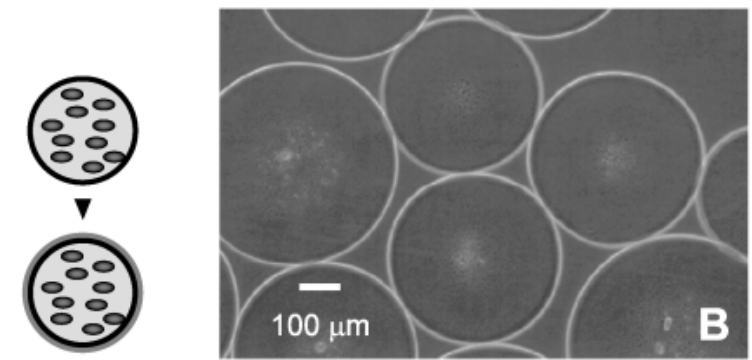

3)
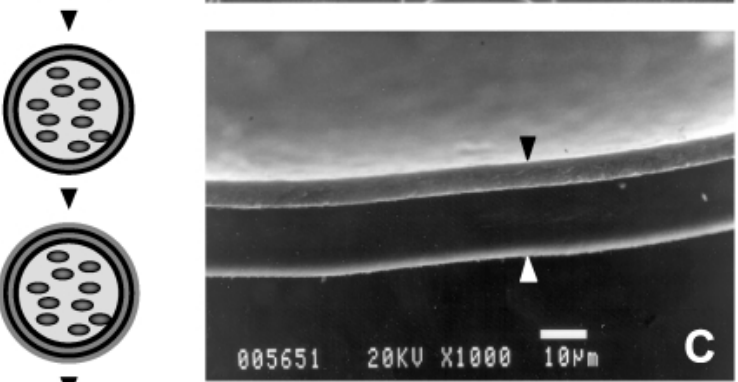

5)

4)
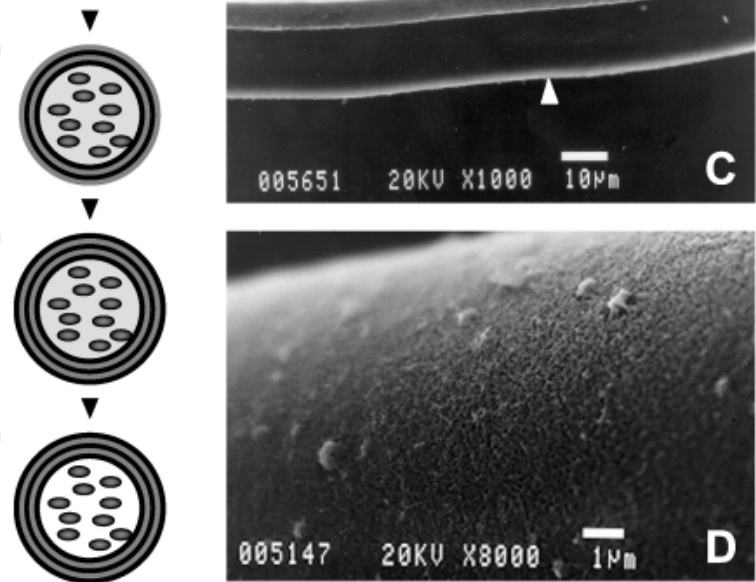

Fig. 2. Preparation Procedures (A) and Structure (B-D) of APA Microcapsules

(A) : 1) Cell suspension with $1.8(\mathrm{w} / \mathrm{v}) \%$ sodium alginate/saline was extruded through a 22 -gauge needle with an air jet into $100 \mathrm{mM} \mathrm{CaCl}_{2}$ solution to form calcium alginate gel microbeads. 2) The microbeads were immersed into $0.1(\mathrm{w} / \mathrm{v}) \%$ poly $(\mathrm{L})$ lysine/saline for $10 \mathrm{~min}$ to cross-link the negatively charged their surface with polycations. 3) After washed with saline, the microbeads were suspended in $0.03(\mathrm{w} / \mathrm{v}) \%$ sodium alginate/saline for 4 min. 4) and 5) To create a thicker membrane, the microbeads were resuspended in $0.1(\mathrm{w} / \mathrm{v}) \%$ poly $(\mathrm{L})$ lysine/saline followed by $0.03(\mathrm{w} / \mathrm{v}) \%$ sodium alginate/saline using the same protocol as described above. 6) After washing, the microbeads were suspended in $55 \mathrm{~mm}$ sodium citrate for $5 \mathrm{~min}$, then thoroughly washed with saline to remove excess citrate and liquefied alginate. (B): Empty APA microcapsules were photographed under phase contrast microscope. The diameter of the APA microcapsules was 400-600 $\mu \mathrm{m}$. (C) : A scanning electron microscopic image of the APA membrane section. Midpoint between two arrowheads shows thickness of APA membrane. (D) : APA microcapsules under a scanning electron microscope revealed a smooth surface.

マイクロカプセル表面における fibrosis や投与に伴 う腹水貯留・腹腔内への炎症細胞浸潤等の所見は認

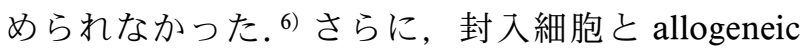
な関係のマウスに投与した APA マイクロカプセル は，封入細胞に対する宿主免疫応答の誘導を抑制 し，あらかじめ封入細胞に対する特異的免疫を成立 させた宿主内においてさえ，封入細胞の形態・機能 を正常に維持することができた. ${ }^{4)}$ これらの結果は,

APA マイクロカプセルが，(1)細胞傷害性や起炎性 
がないこと，(2)細胞封入操作において過激な反応条 件を伴わず操作が短時間で完了すること，(3)物理 的・化学的に安定であり，生体内で容易に分解・破 壊されないこと，(4)物質の透過が制御可能であるこ と，(5)免疫反応による傷害から封入細胞を保護でき ること，等の細胞性製剤を創製する上で備えるべき 条件を満足する担体であることを示している.

2-2. 膵 $\beta$ 細胞株封入 APA マイクロカプセルの 糖尿病治療への応用膵 $\beta$ 細胞は血中のグル コース濃度を感知し，必要量のインスリンを分泌す ることで血糖值を定常域に維持している。この膵 $\beta$ 細胞が自己免疫疾患等により破壊され，正常なイン スリン分泌が行われず高血糖に陥る疾患が I 型糖尿 病であり，患者は生涯に渡りインスリン投与を必要 とする．インスリンペンの登場によって頻回投与が 簡便になったとは言え，本治療法による血糖值コン トロールは患者のコンプライアンスに依存してお り，糖尿病合併症やインスリン過剩投与による低血 糖症の誘発と言う危険性を孕んでいる。したがつ て， I 型糖尿病における理想的なインスリン療法を 達成するためには，患者の負担を軽減し，厳密かつ 自動的に血糖值をコントロールし得る製剤の開発が 切望されている。

近年，膵 $\beta$ 細胞のグルコース応答性インスリン 分泌機構の解明が進められ，それらの研究の中で正 常なグルコースセンサー機能を有する数種の膵 $\beta$ 細胞株が樹立された。これらの膵 $\beta$ 細胞株は，培 養維持の簡便性や大量調製が可能であるなど，細胞 性製剤の素材として利用するための大きなメリット を有している。そこで筆者らは，C57BL/6 マウス 由来膵 $\beta$ 細胞株である MIN6 細胞を APA マイクロ カプセルに封入した細胞性製剂（APA-MIN6）を 創製し，その I 型糖尿病治療における有用性を評価 した. ${ }^{6}$ まず，APA-MIN6 の機能及び特性をin vitro 培養系で検討したところ，APA マイクロカプ セル内で MIN6 細胞は良好な増殖を示し，少なく とも 3 力月間に渡って生存していることが明らかと なった。 また，種々の濃度のグルコースを含む緩衝 液中において APA-MIN6 のインスリン分泌プロフ アイルを解析した結果，生理的な血中グルコース濃 度以下においては APA-MIN6からインスリンはほ とんど分泌されず，正常血糖值を超えた範囲で初め て大幅なインスリン分泌充進が観察された（Fig.
3).この APA-MIN6 によるグルコース応答性イン スリン分泌機能は, APA マイクロカプセルに封入 していない MIN6 細胞における分泌機能と同等で あり，APA マイクロカプセルへの封入操作が MIN6 細胞の機能特性に影響を与えないことを示し ている.

そこで次に，ストレプトゾトシンを投与すること によって I 型糖尿病を誘発した BALB/c マウスに APA-MIN6 を腹腔内投与し, 経日的に血糖值をモ ニタリングすることにより APA-MIN6 の細胞性製 剂としての有効性を検証した（Fig. 4)。血糖值が $400 \mathrm{mg} / \mathrm{dl}$ 以上を示す糖尿病マウスに APA-MIN6 を投与した場合，投与後 4 日目には血糖値が正常值 にまで低下し，宿主と細胞性製剂が allogeneic な関 係であるにも関わらず，わずか 1 回の投与で 2 力月 以上に渡って正常血糖値を維持することができた. またこの間，低血糖症を示す個体は認められず, APA-MIN6 投与後 4 日目までの高血糖状態におい ては血中に高濃度のインスリンが検出されたが，正 常血糖值に到達した後の血中インスリン濃度は正常 マウスと同等の約 $1 \mathrm{ng} / \mathrm{ml}$ に維持されていた.さら に，経口糖負荷試験における正常マウスと APAMIN6 投与マウスの血中インスリン濃度推移を比較 したところ，糖負荷後の血中インスリン濃度の上昇

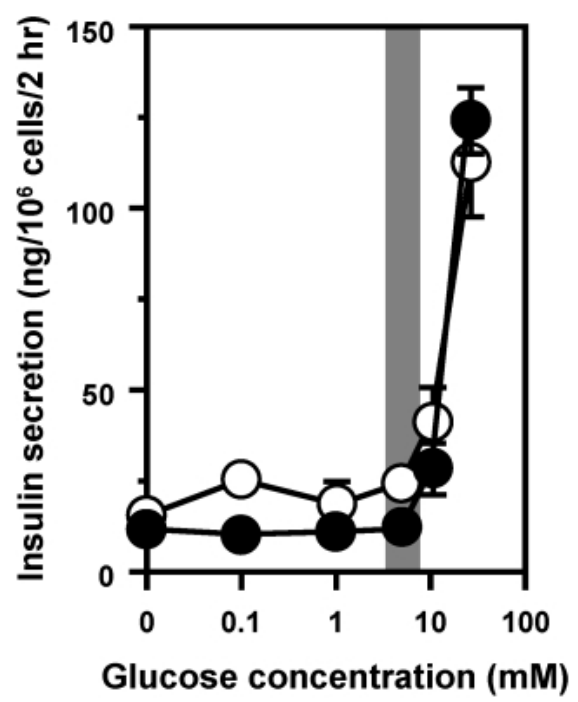

Fig. 3. Glucose-stimulated Insulin Secretion from MIN6 Cells and APA-MIN6 In vitro

MIN6 cells $(O)$ or APA-MIN6 (O) were incubated for $2 \mathrm{~h}$ in KrebsRinger bicarbonate buffer containing glucose at various concentrations. Supernatants were collected and measured for insulin by ELISA. A gray range in the panel expresses physiological blood glucose level. 


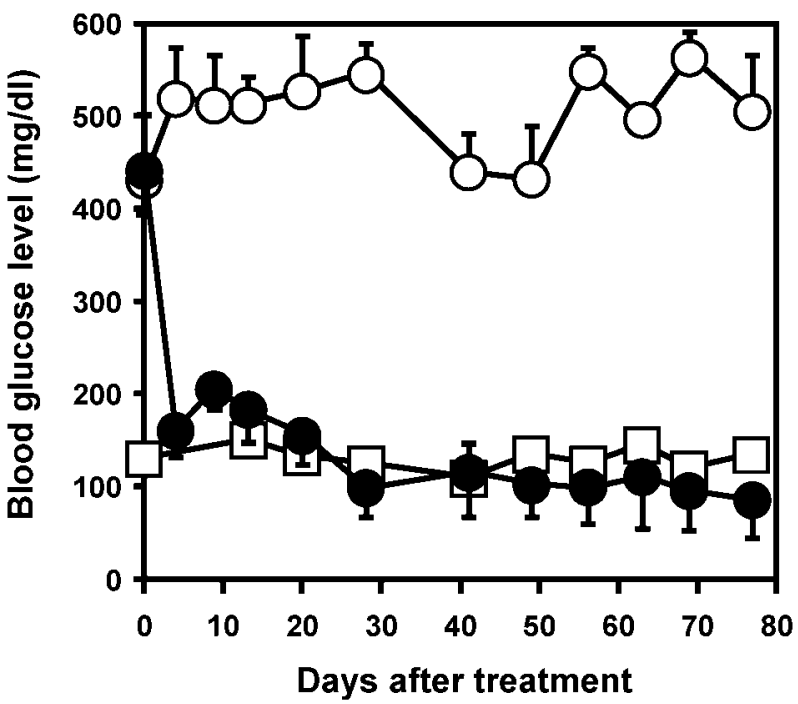

Fig. 4. Blood Glucose Level of Diabetic Mice Injected with APA-MIN6

APA-MIN6 containing $5 \times 10^{6}$ MIN6 cells $\left(\mathrm{H}-2^{\mathrm{b}}\right)$ was intraperitoneally injected into $\mathrm{BALB} / \mathrm{c}$ mice $\left(\mathrm{H}-2^{\mathrm{d}}\right)$ with streptozotocin-induced diabetes. Blood glucose levels of normal $(\square)$ and diabetic mice $(O)$, and of diabetic mice injected with APA-MIN6 (-) were measured by Glucose CII Test WAKO.

並びに血糖值低下に伴った減少が同様のパターンを 示したことから，APA-MIN6 は allogeneic な宿主 体内においても正常なグルコース応答性インスリン 分泌機能を保持していることが実証された.

以上に紹介した筆者らの成果は，細胞に備わった （あるいは付与した）DDS 的機能を薬物治療へと展 開できる可能性を示した好例であり，今後マイクロ カプセル型細胞性製剂の免疫隔離性並びに安全性を さらに高める技術の蓄積によって，将来的には非自 己の機能性細胞を免疫学的な壁を越えて応用可能な 細胞療法の実現に結び付くものと期待している.

\section{3. 遺伝子導入による細胞への機能付与を基盤と}

\section{する細胞療法}

細胞の分離・加工・培養技術が進歩したことによ り，樹状細胞 $(\mathrm{DC}) \cdot \mathrm{T}$ 細胞などを用いた細胞免疫 療法や, 胚性幹細胞 $(\mathrm{ES}$ 細胞) ・組織幹細胞を用い た再生医療が，難治性疾患に対する次世代治療戦略 として注目を集めている。これらの細胞療法に使用 する細胞性製剂は主として患者自身から分離した細 胞を素材とするが，そのままの状態で生体に投与し て疾病治療に有効であるケースは稀であり，増殖因 子・分化因子による細胞の大量調製や分化制御はも ちろんのこと, 遺伝子・タンパク質等の細胞内送達 によって機能の付与あるいは最適化を図るといった
細胞加工技術が必要とされる.

細胞への物質導入について水口らは，センダイウ イルス由来のエンベロープタンパクを表面に有する 膜融合リポソームを開発し，核酸・タンパク質・ペ プチドに留まらずナノ粒子と言つたリポソームに封 入可能な物質であれば，ほぼすべての動物細胞へ効 率よく導入できることを報告している. ${ }^{10-14)}$ 本技 術は膜融合リポソームが細胞膜と融合することによ つて封入物質を細胞質内へ直接送達できることか ら，エンドサイトーシスを介して取り込まれる経路 と異なり導入物質のエンドソーム/リソソーム系に よる分解を回避しつつ，さらには細胞内での物質徐 放や細胞内オルガネラへの選択的物質送達をも達成 できる可能性を秘めた細胞加工技術として有望であ る. ${ }^{13,14)}$ 一方, 遺伝子治療研究におけるべクター技 術の進展に伴って，これまで十分な外来遺伝子発現 を誘導することが困難とされてきたある種の癌細 胞, 血球系細胞及び幹細胞への効率的な遺伝子導入 を可能とする新規ベクターシステムが開発されてき た. 今後，これらの基盤技術の応用によって新たに 創製された機能性細胞の細胞療法への展開が飛躍的 に拡充していくものと思われ，その一例として筆者 らが進めている遺伝子改変 DC の創製とその癌免疫 療法への応用に関するアプローチを以下に紹介する.

3-1. DCへの遺伝子導入システムの構築 癌 に対する免疫応答を細胞・分子レベルで解析する腫 瘍免疫学の進展は，遺伝子変異を蓄積した癌細胞が 質的・量的に正常細胞とは異なる分子を発現してお り，これら腫瘍関連抗原（TAA）と呼ばれる分子 に対する免疫監視機構が初期癌細胞の排除と言う生 体の恒常性維持に重要な役割を果たしていることを 明らかとした。しかし, 癌細胞は本来的には自己の 細胞であり，外界から侵入してくる異物（非自己） と比較すると免疫原性は非常に微弱であることか ら, 免疫監視機構を潜り抜けて増殖・転移した癌細 胞は生体機能を侵蝕することとなる。また, 癌細胞 自身が分泌する液性因子によって免疫機能が破綻を 来すことも知られており，腫瘍として発見された疾 患状態を生来の免疫力のみで回復させることは困難 である.したがって，癌に対する免疫療法研究にお いては，患者の免疫系に癌細胞の特徵（正常細胞と の差異）を増幅して効率よく認識させることのでき るアジュバントの開発が極めて重要である. 
近年，免疫系を構成する細胞の機能解明が急速に 進んだことによって，DC が $\mathrm{T}$ 細胞依存性の獲得免 疫応答の始動及び増幅，さらには自然免疫応答の制 御をも含めて，免疫監視機構を多方面から統御する 抗原提示細胞であることが明らかとなり，癌や感染 症を対象とした免疫療法開発における標的細胞とし て注目を集めている，骨髄幹細胞に由来する DC は 未熟な状態で生体内に広く分布しており，旺盛な領 食能によって外界から侵入してきた病原体あるいは 癌細胞やウイルス感染細胞の断片を捕食する。抗原 を細胞内に取り込んだ DC は成熟し，細胞表面に主 要組織適合遺伝子複合体 $(\mathrm{MHC})$ 分子 • 共刺激分 子と言つた抗原提示に必要な機能分子の発現を高め るとともに，取り込んだ抗原を MHC class I 及び class II 分子とともに細胞表面に提示可能なペプチド にまでプロセッシングする，さらに，輸入リンパ管 や血管を介して最寄りのリンパ組織へと遊走し，リ ンパ組織に存在するナイーブ $\mathrm{T}$ 細胞へ抗原提示す ることにより, 抗原特異的 $\mathrm{T}$ 細胞依存性の初期免疫
応答を惹起する (Fig. 5). 15,16) このような免疫学的 特性に基づいて，TAA を導入した DC を“nature’s adjuvant”として利用する細胞免疫療法が有望な新 規癌治療戦略として活発に研究されており，DCの 腫瘍免疫誘導能を最大限に発揮させる方法論の探索 が進められている.17) なかでも，生体に投与する $\mathrm{DC}$ への効率のよい TAA デリバリー法の確立は, DC 免疫療法の有効性に直結する重要な検討課題で あり，持続的な TAA 供給を可能とする観点から， $\mathrm{DC} へ$ の $\mathrm{TAA}$ 遺伝子導入は非常に魅力的なアプ ローチである。しかし，従来のいかなる遺伝子導入 法によっても DCへの遺伝子導入効率は極めて低 $<$, 広範な種類の細胞・組織に最も効率よく遺伝子 導入可能とされるアデノウイルス（Ad）ベクター を用いてさえ, DC に外来遺伝子を十分に発現させ

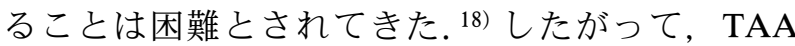
遺伝子を導入した DCによる有効な癌免疫療法を開 発するためには，細胞傷害性を示すことなく高い効 率で DC に遺伝子導入できる新規ベクターシステム

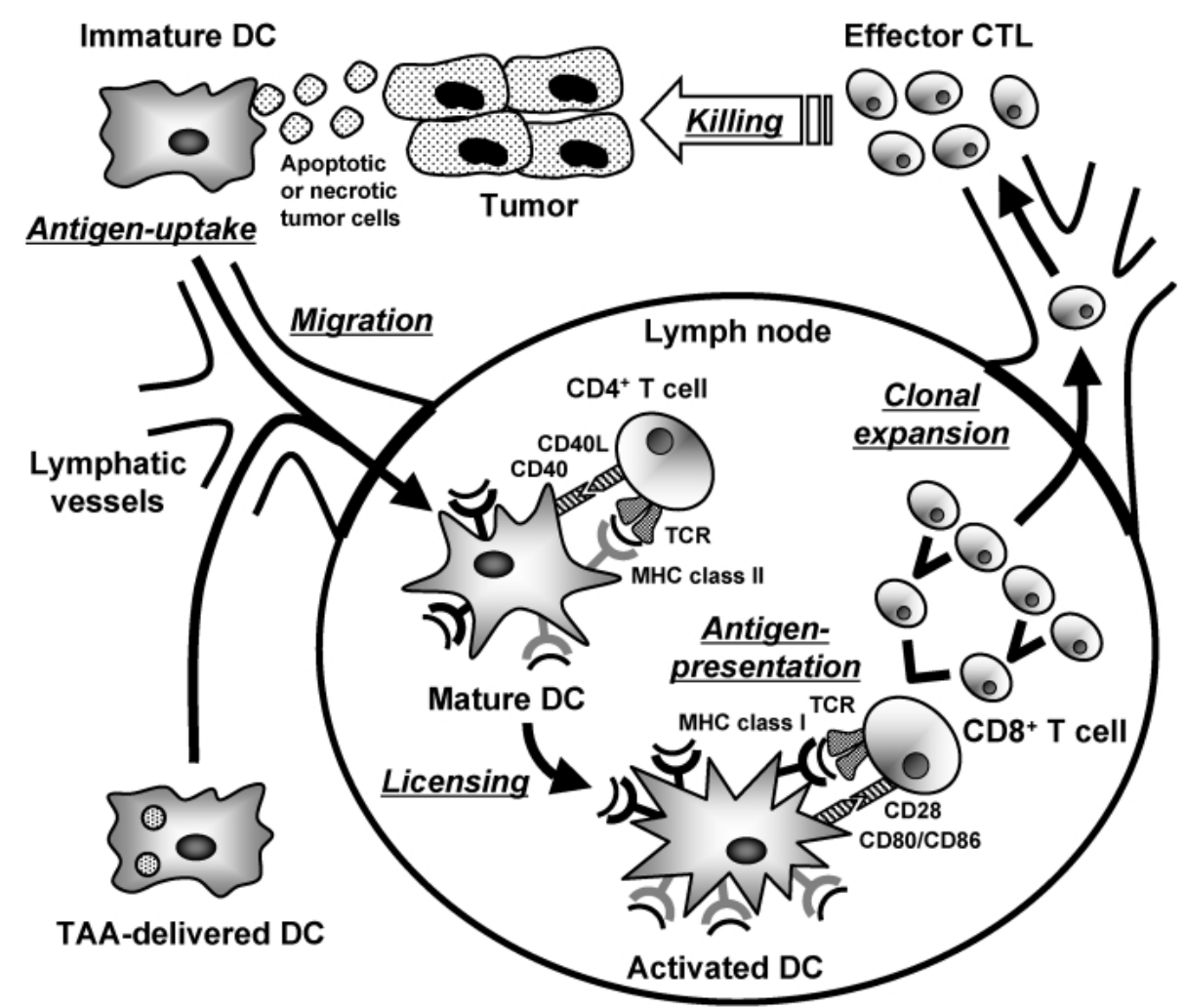

Fig. 5. A Schematic Representation of Roles of DCs for Induction of T Cell-dependent Tumor Immunity

Apoptotic or necrotic tumor cells containing TAAs are captured by immature DCs in tumor tissue and processed to form MHC-antigenic peptide complexes. As a consequence of antigen deposition and inflammation, DCs begin to mature, expressing large amounts of MHC-peptide complexes on their surface. Additionally, they up-regulate costimulatory molecules and migrate to regional lymph node where they prime and activate antigen-specific T cells. Clonally expanded CTLs distribute to peripheral tissues through lymph vessels and blood, and eliminate tumor cells by perforin-granzyme dependent manner or Fas-FasL death signaling pathway in tumor tissue. DC-based cancer immunotherapy is aimed for amplification of these serial immune reactions by administration of TAA-delivered DCs. 
の開発が急務であつた.

本観点から筆者らは，カチオニックリポソーム， 膜融合リポソーム, 細胞膜透過ペプチド, $\mathrm{Ad} ヘ ゙ ク$ ター等を利用した DCへの遺伝子送達技術の最適化 を試みた。19-21）その結果， $\alpha_{\mathrm{v}}$-integrin に親和性を有 する RGD（Arg-Gly-Asp）配列をカプシドタンパ ク質のファイバー領域に挿入した新規 RGD ファイ バーミュータントアデノウイルス (AdRGD) ベク ターを用いることにより，世界に先駆けて極めて効 率に優れる DCへの遺伝子導入システムを構築する ことに成功した. ${ }^{21,22)}$ 現在の遺伝子治療研究や遺伝 子機能解析において用いられている $\mathrm{Ad}$ ベクターは 2 型あるいは 5 型ヒト Ad を基本骨格とし，252 個 のカプソメアからなる正 20 面体構造の 12 個の頂点 にはペントン（ファイバーとペントンベースからな る）と呼ばれる突起構造が存在する。 Ad ベクター
が標的細胞内に侵入するには，ファイバー先端部が 細胞表面上の coxsackievirus-adenovirus receptor （CAR）に結合し，その後ペントンベースの RGD モチーフが $\alpha_{\mathrm{v}} \beta_{3}$-あるいは $\alpha_{\mathrm{v}} \beta_{5}$-integrin に結合す る，という 2 段階の過程が必要である. ${ }^{23,24)}$ そこで DC におけるこれら Ad 感染受容体の発現レベルを 解析したところ，CAR の発現が非常に乏しいこと が DC の Ad ベクター介在性遺伝子導入に対する抵 抗性の原因であり，一方 $\alpha_{\mathrm{v}}$-integrins は DCにも豊 富に発現していることが明らかとなつた. ${ }^{21,22)}$ 本結 果に基づいて，共同研究者の水口裕之博士（医薬基 盤研究所）らが開発した簡便なファイバーミュータ ントAd ベクター構築法25-27)に準拠して, ファイ バーの HI loop に RGD ペプチドを挿入した $\alpha_{\mathrm{v}}$-integrin 指向性 AdRGD ベクターを作製した（Fig. 6).レポーター遺伝子として緑色蛍光タンパク

\section{RGD fiber-mutant adenovirus (AdRGD) vector}

CG AAG TGT GAC TGC CGC GGA GAC TGT TTC TG TTC ACA CTG ACG GCG CCT CTG ACA AAG ACG C

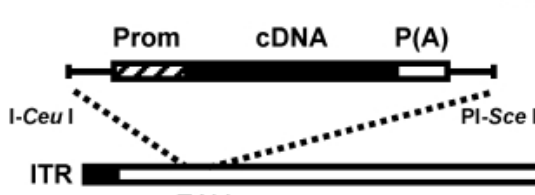

E1(-)

$(342-3528)$
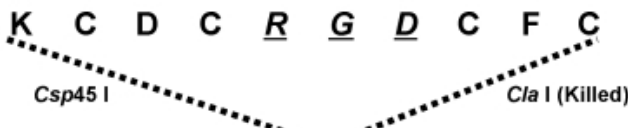

E3(-)

(28133-30818) 드 fiber coding region

Conventional Ad vector
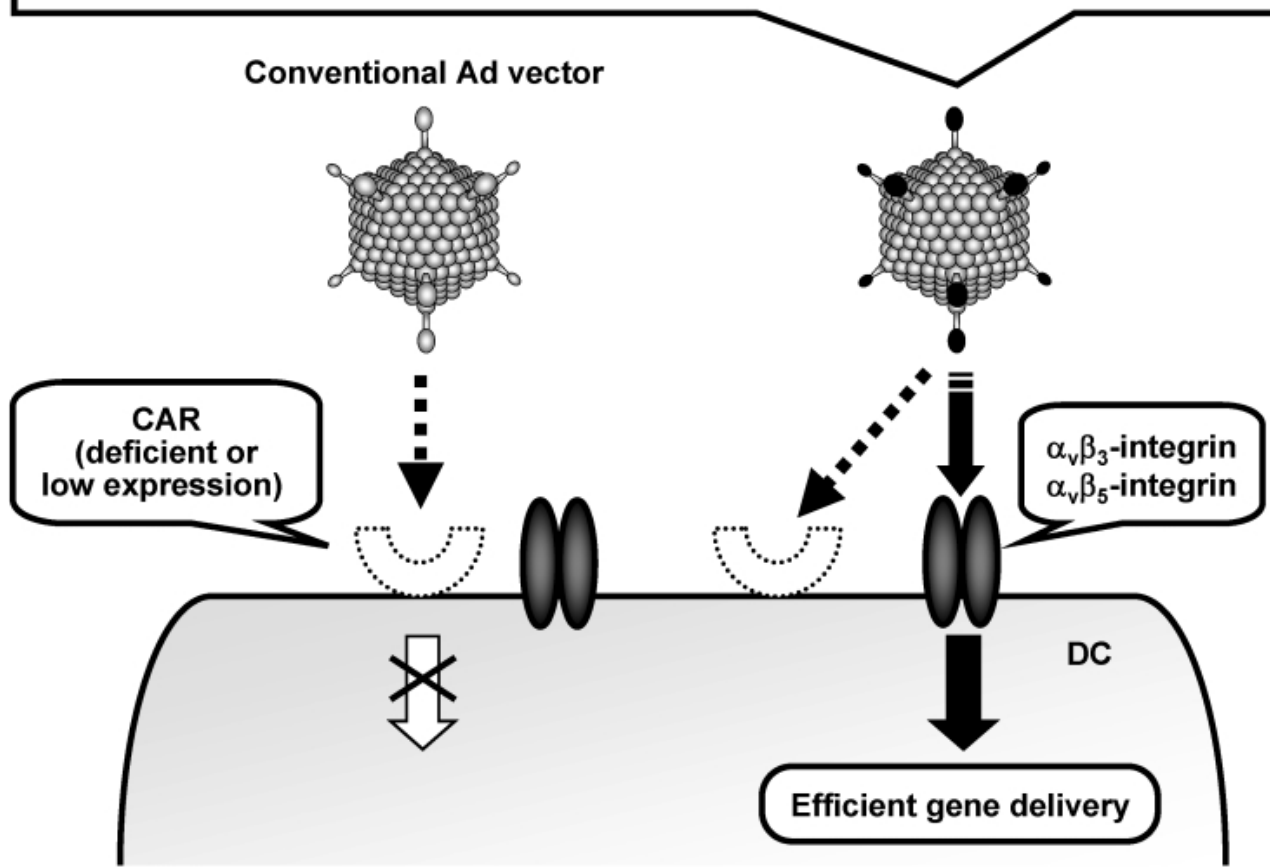

Fig. 6. A Schematic Representation of RGD Fiber-mutant Adenovirus (AdRGD) Vector ITR: inverted terminal repeat, Prom: promoter, $\mathrm{P}(\mathrm{A})$ : polyadenylation signal. 
（EGFP）遺伝子を搭載した AdRGD ベクター及び 従来型 $\mathrm{Ad}$ ベクターをマウス骨髄由来 DC に適用し たところ，従来型 Ad-EGFP では 10-15\%の遺伝 子導入効率しか得られない感染力価 (multiplicity of infection; MOI) において, AdRGD-EGFP は細 胞傷害性を示すことなく $90 \%$ 以上の DC に外来遺 伝子発現を誘導することができた（Fig. 7). ${ }^{22)} ま$ た，ヒト末梢血単球由来 DCにおいても同様の結果 が認められ，21) さらに抗 $\alpha_{\mathrm{v}}$-integrin 抗体を用いた阻 害実験により，当初の目的通り AdRGD ベクター は標的細胞への結合に $\alpha_{v}$-integrin 指向性を有する ことが確認された. ${ }^{28)}$

3-2. TAA 遺伝子導入 DC ワクチンの創製と癌 免疫療法への応用 メラノーマは TAA 解析が進 んでいる数少ない癌の 1 つであり, メラノサイトの 分化並びにメラニン形成に関与する gp100, MART1， tyrosinase，TRP などがメラノーマ関連抗原 （MAA）としてこれまでに同定されている。 マウ ス及びヒトメラノーマで構成的に過剩発現している gp100 は，高い免疫原性を有することからヒトを対

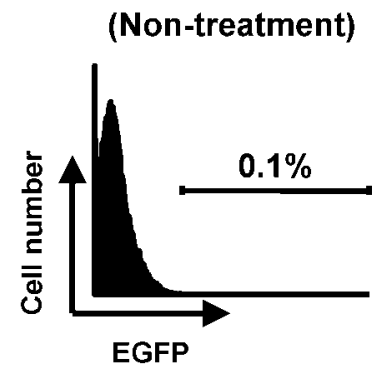

(25 MOl)

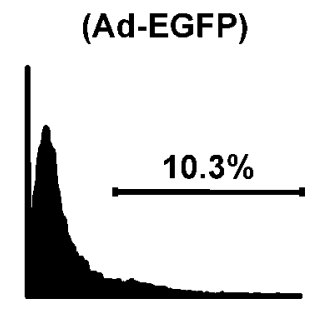

(AdRGD-EGFP)

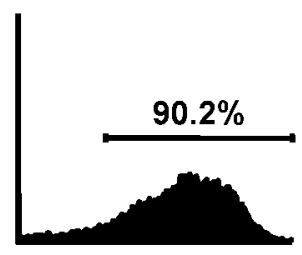

(50 MOI)
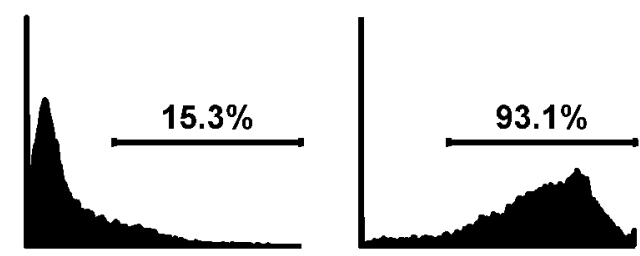

Fig. 7. EGFP Expression in Murine DCs Transduced with EGFP cDNA by AdRGD or Conventional Ad Vector

DCs were transfected for $2 \mathrm{~h}$ with Ad-EGFP or AdRGD-EGFP at 25 or 50 MOI. Two days later, EGFP expression in cells was evaluated by flow cytometric analysis. The \% value expresses \% of EGFP-positive DCs.
象とした特異的免疫療法における重要な標的分子と 考えられており，MHC class I 分子上に提示される gp100 ペプチドを用いた癌免疫療法の第 I / II 相臨 床試験が既に試みられている．また，gp100を含め た MAA を標的とする癌免疫療法の前臨床試験に は，ほとんどのヒト MAA homolog を発現してい るマウス B16 メラノーマモデルが広く用いられて いる.

そこで，DCへの遺伝子導入効率における AdRGD ベクターの優位性が，TAA を標的とした DC 免疫療法の有効性向上に反映されるのかについ て検討した．まず，AdRGD ベクターにより抗原遺 伝子を導入した DC の免疫学的機能を in vitro 培養 系で精查したところ， $\mathrm{T}$ 細胞に対する抗原提示能及 び増殖刺激能ともに従来型 Ad ベクターを適用した DC と比較して大幅に改善されていることが判明し た. ${ }^{21,22,29,30)}$ 次に, AdRGD ベクターあるいは従来 型 Ad ベクターにより gp100 遺伝子を導入した DC （AdRGD-gp100/DC 及び Ad-gp100/DC）をマウ スにワクチン接種し，その後攻撃接種した B16BL6 メラノーマに対する増殖抑制効果を比較した（Fig. 8). ${ }^{30)}$ コントロールベクターである AdRGD-Null を適用した DC （AdRGD-Null/DC）を投与したマ

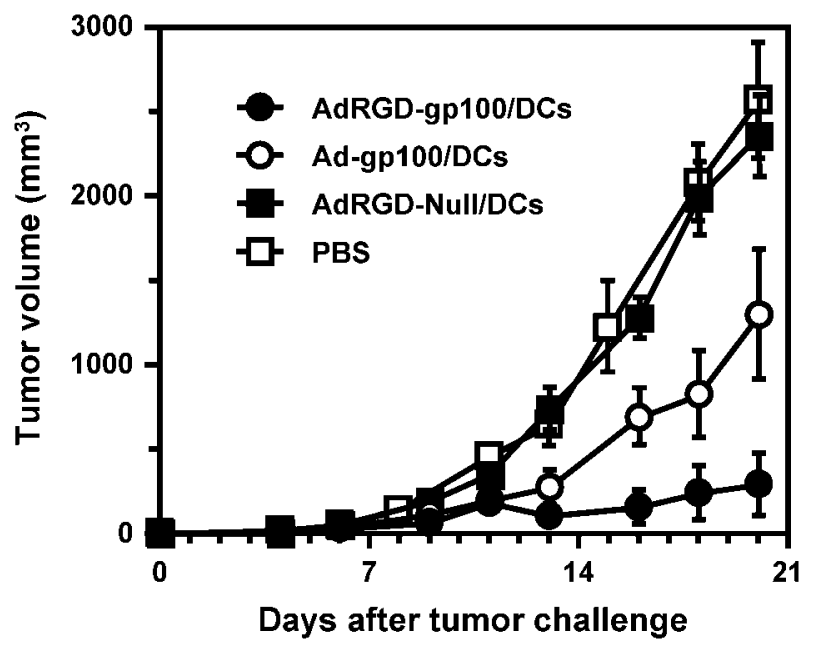

Fig. 8. Vaccine Efficacy of DCs Transduced with gp100 cDNA by AdRGD or Conventional Ad Vector against B16BL6 Melanoma Challenge

AdRGD-gp100/DCs, Ad-gp100/DCs, and AdRGD-Null/DCs were prepared using corresponding vectors at $50 \mathrm{MOI}$. C57BL $/ 6$ mice were immunized by intradermal injection of transduced DCs into the right flank at $10^{6}$ cells, and then $2 \times 10^{5}$ B16BL6 melanoma cells were inoculated into the mouse left flank after 1 week post-vaccination. The size of tumors was assessed using microcalipers three times per week, and the tumor volume was calculated by the following formula: (tumor volume; $\left.\mathrm{mm}^{3}\right)=($ major axis; $\mathrm{mm}) \times(\text { minor axis; } \mathrm{mm})^{2} \times 0.5236$. 
ウスでは, vehicle 投与群と比較して腫瘍増殖抑制 効果は全く認められなかったが， $\mathrm{Ad}-\mathrm{gp} 100 / \mathrm{DC}$ 投 与群においては明らかな腫瘍増殖の遅延が観察され た。さらに AdRGD-gp100/DC 投与群では, 攻撃 接種した B16BL6 腫瘍の増殖をより強力に抑制し, 6 例中 4 例で腫瘍の完全拒絶が達成された。 また, AdRGD-gp100/DC あるいは Ad-gp100/DC 投与に よる B16BL6 肺転移抑制効果を比較したところ, ワクチンプロトコール（DC 投与 1 週間後に B16BL6 細胞を尾静脈内投与）及び治療プロトコー ル（B16BL6 細胞を尾静脈内投与後，DC を 3 回投 与）のいずれにおいても AdRGD-gp100/DC 投与 群でより顕著な肺転移結節数の減少を認めた. ${ }^{30)} こ$ れらの抗腫瘍効果に関与する免疫エフェクタ一細胞 は, in vivo depletion assay の結果から $\mathrm{CD}^{+} \mathrm{T}$ 細胞 であることが明らかとなり，さらに AdRGD-gp100 /DC をワクチン投与したマウスの脾細胞中には, Ad-gp100/DC 投与群よりも高い B16BL6 特異的傷 害活性が検出されたことから，AdRGD-gp100/DC が効率よく腫瘍特異的な細胞傷害性 $\mathrm{T}$ 細胞 $(\mathrm{CTL})$ の活性化並びに増幅を誘導したことが実証され た. ${ }^{30)}$

これらの結果は，AdRGD ベクターを応用した TAA 遺伝子導入 DC ワクチンの創製が，これまで DC に対する低い TAA 導入効率によって制限され ていた DC 癌免疫療法の有効性を飛躍的に改善でき ることを示すものである．また，AdRGD ベクター システムは DCへの抗原遺伝子デリバリーのみなら ず，従来の遺伝子導入法では困難とされてきた種々 の機能修飾を目的とする遺伝子改変 DC の創製をも 可能とする. ${ }^{31,32)}$ したがって，AdRGD ベクターを 用いた DCへの効率的な遺伝子導入は，臨床的に最 適な DC ワクチンを設計・開発するためのブレーク スルー的な手法になり得ると期待される.

\section{4. 免疫細胞の体内動態制御を基盤とする細胞療} 法

細胞療法の有効性及び安全性を確保・向上するた めには，生体に投与した細胞性製剤並びに細胞性製 剤によって情報伝達された細胞を「必要な時に，必 要な場所に, 必要な量」送達できる “Cell Delivery System”とも言うべき新たな概念・方法論の確立が 必要とされる（Fig. 9）。しかし，生体を構成する 約 60 兆個の細胞の秩序を保った移動・分布・配列
等を制御する巧妙な仕組みに関する知見はいまだそ しく, Cell Delivery System の構築へと展開できる 基礎情報並びに基盤技術は限られている，現時点で Cell Delivery System への応用に最も利用価値の高 い生命現象は，ケモカインーケモカインレセプター 連関に基づいた免疫細胞の局所への遊走・浸潤制御 機構であろう。

ケモカインは 8-14 kDa 程度の塩基性・ヘパリ ン結合性分泌タンパク群であり，種々の細胞接着分 子と協調して炎症反応やリンパ球のホーミングを制 御している. ${ }^{33)}$ 現在, ヒトでは約 50 種類のケモカ インが同定されており，それらは保存された 4 つの システイン残基のうち $\mathrm{N}$ 末端の 2 個のシステイン の位置から C ケモカイン, CC ケモカイン, CXC ケモカイン, 及び CX3C ケモカインの 4 つのサブ グループに分類されるスーパーファミリーを形成し ている. ${ }^{34)}$ また, すべてのケモカインは 7 回膜貫通 $\mathrm{G}$ タンパク質共役型レセプターを介して作用し, 同定されている約 20 種類のケモカインレセプター もスーパーファミリーを構築している. ${ }^{35,36)}$ ケモカ インは当初, 好中球や単球を遊走させるサイトカイ ンの一群として発見され, 主に炎症での役割が研究 されてきた。これら炎症性ケモカインに対して, 1990 年代後半より, バイオインフォマティクスを 駆使して EST データベースを検索するという手法 によって新しいケモカインが次々と発見され，リン パ球や DC などを標的細胞とする免疫系ケモカイン の存在が明らかとなった。これによって，免疫細胞 の生体内での移動や局在の制御機構に関する理解が 急速に進展するとともに, ケモカインーケモカイン レセプター連関を応用することによって免疫細胞の 体内動態・体内分布を制御し得る新たな癌免疫療法 の開発に足掛かりができた.

前述の通り AdRGD ベクターによる DC 遺伝子 修飾法は，DCへの効率のよい TAA 遺伝子デリバ リーはもとより，DCに機能分子を強制発現させる ことでこれまでにない強力な DC ワクチン（細胞性 製剤）の創製とその実証的解析を可能とする。この コンセプトに基づいて筆者らは，ケモカイン遺伝子 あるいはケモカインレセプター遺伝子を搭載した AdRGD ベクターを応用することにより，生体に投 与する DC ワクチン自身及び DC ワクチンに応答す る免疫エフェクター細胞の体内動態を操作し，より 


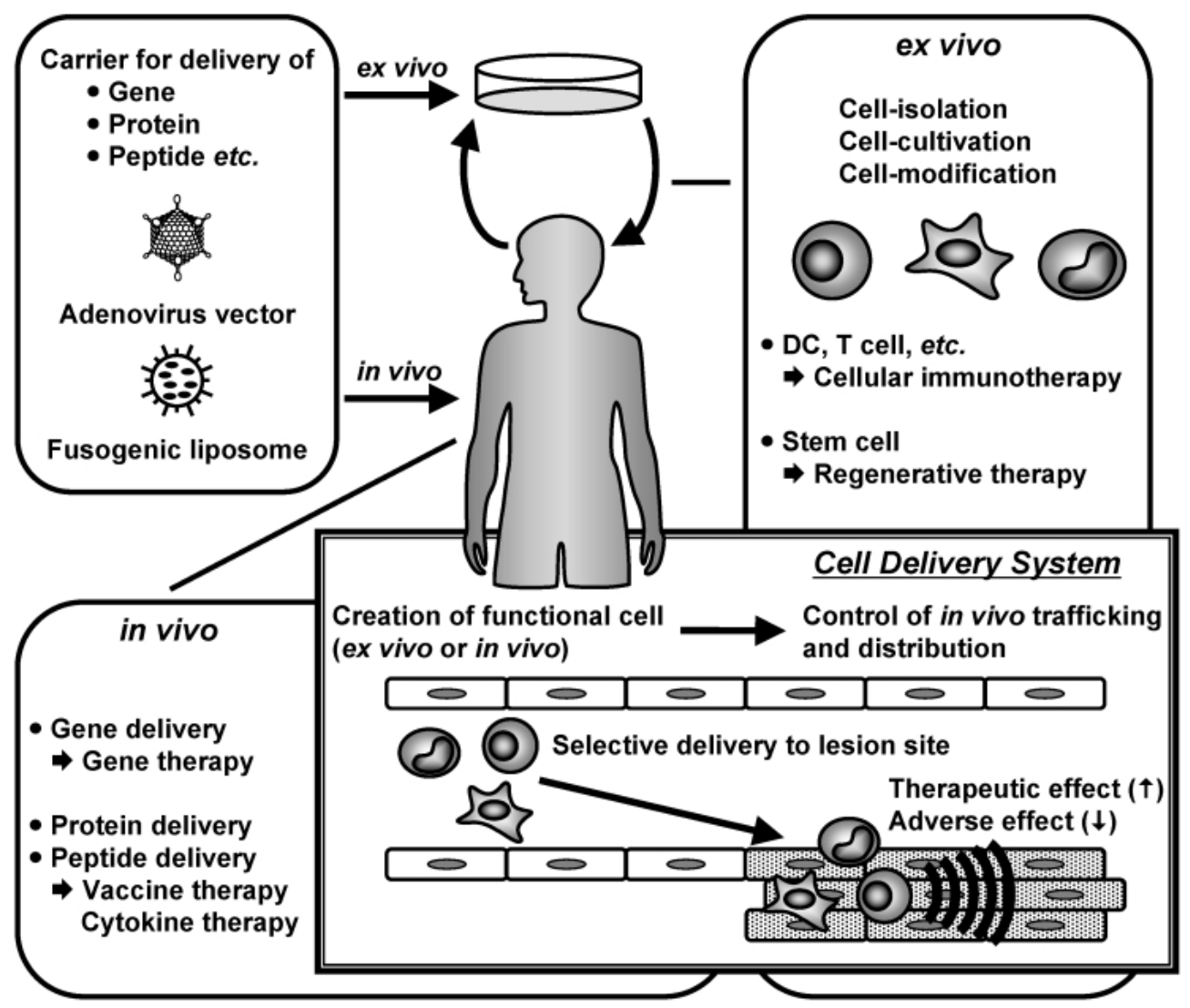

Fig. 9. “Cell Delivery System” Based on Manipulation of Cell-trafficking and Biodistribution in Cell Therapy

効果的な癌免疫遺伝子治療の開発へと発展させると いう独自のアイディアを実践している. $32,37,38)$ その 一例として，CC ケモカインレセプター7（CCR7） 遺伝子を導入することでリンパ組織指向性を増強し た DC ワクチンの創製とその癌免疫療法における有 用性を紹介する。

4-1. リンパ組織指向性 DC ワクチンの設計・創 製生体に投与した DC ワクチンは，投与部位か ら所属リンパ組織へ移行することによって初めて T 細胞への抗原提示・感作を行い一連の初期免疫応答 を惹起する。すすなわち，患者に投与した抗原導入 DCのリンパ組織集積性が，DC 免疫療法の治療効 果を規定する要因の 1 つとして考えられる. しかし 現在の DC 免疫療法では，投与部位からリンパ組織 に移行させるための最適な DC コンディショニング について十分な検討がなされていないため，投与 DC ワクチンのうちリンパ組織に集積するものはわ ずか $0.1-1 \%$ 程度とされている. ${ }^{39-41)}$ したがっ て，生体に投与する DC に高いリンパ組織移行能を 付与することができれば，リンパ組織における免疫 エフェクター細胞の活性化を増強することが可能で
あり，ひいては DC 免疫療法の有効性の飛躍的な改 善に結びつくことが期待される，Gunn らは，CC ケモカインリガンド 21 （CCL21） の発現に欠損が ある plt/plt マウスにおいて，DC の 2 次リンパ組

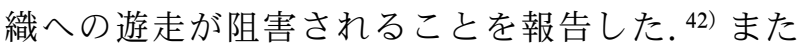
Förster らは，CCR7 ノックアウトマウスにおいて も同様に，DCの 2 次リンパ組織への遊走阻害が起

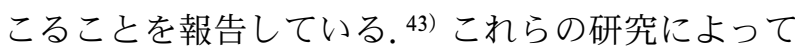
現在では，成熟に伴って DC に発現誘導される CCR7 と, リンパ組織やリンパ管から構成的に産 生・分泌されているCCL21 との連関が，DCの末 梢組織からリンパ組織への遊走制御において中心的 な役割を果たすというコンセンサスが得られてい る。したがって，抗原導入とともに CCR7 を十分 に発現させた DC は，生体に投与したのちに積極的 にリンパ組織へと移行して免疫系を効率よく活性化 できることが強く予測され，この“リンパ組織指向 性 DC”とも言うべき新たなワクチンの創製手段と して DCへの CCR7 遺伝子導入が挙げられる（Fig. 10). ${ }^{32)}$

まず，新たに構築した AdRGD-CCR7 を用いて 
(A)

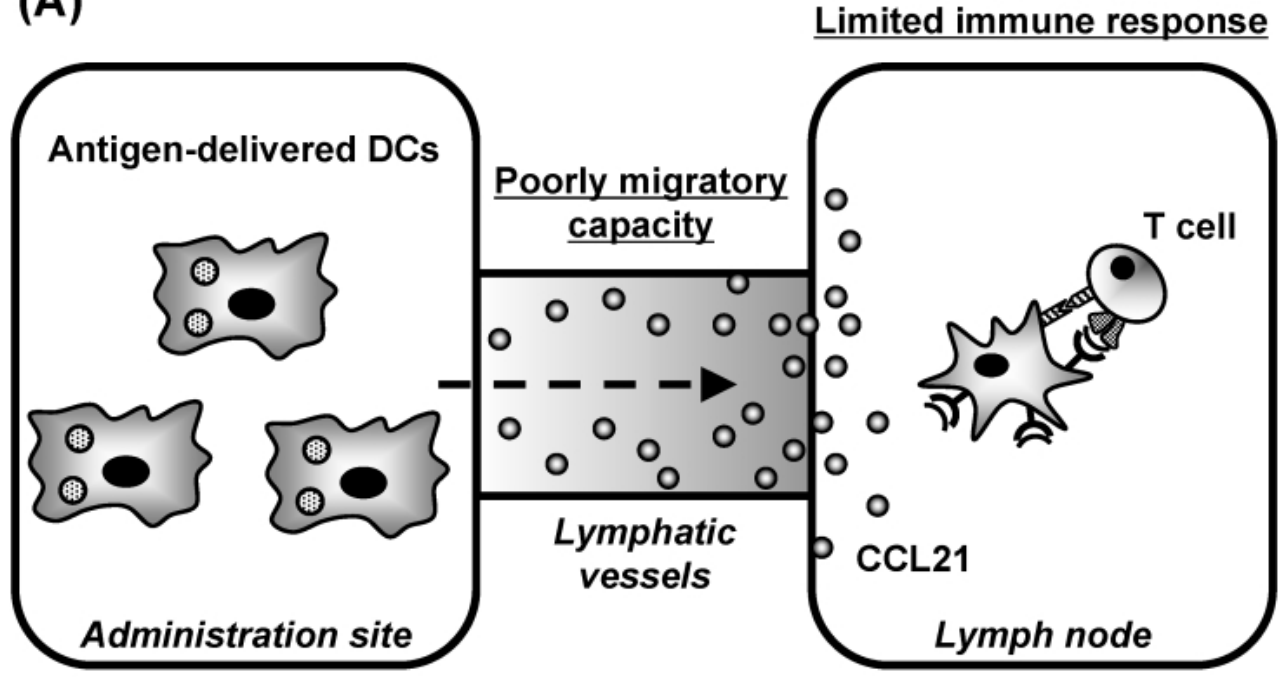

(B)

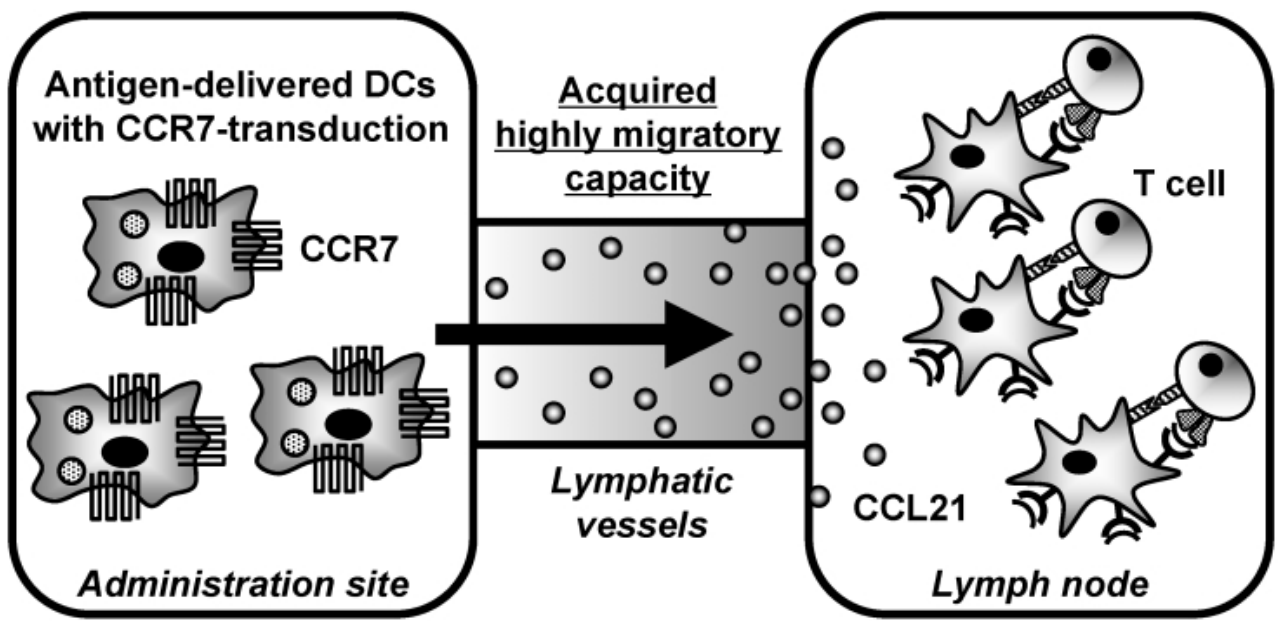

Fig. 10. A Conceptual Representation of "Lymphoid Tissue-directivity DC" Vaccine Created by CCR7 Gene-transduction

The migration of DCs from administration site to lymph node is critical for the priming of T cells in DC-based immunotherapy. However, poorly migratory capacity of antigen-delivered DCs limits the induction of potent immune response (A). On the other hand, DCs transduced efficiently with CCR7 gene may adequately respond to CCL21, which is constitutively released from lymphoid tissue, and acquire highly migratory capacity to lymph node (B). Consequently, antigendelivered DCs with CCR7-transduction can enhance the initiation and amplification of T cell-dependent immune response.

遺伝子導入したマウス骨髄由来 DC $(\mathrm{CCR} 7 / \mathrm{DC})$ における CCR7 発現レベルを RT-PCR 及び flow cytometry により解析した結果, ベクター用量依存 的に CCR7 mRNA の発現は増加し, 50 MOI の感 染力価で AdRGD-CCR7 を適用した際には 90\%以 上の DC で細胞表面に豊富な CCR7 タンパク発現 が確認された。 また，in vitro chemotaxis assay にお いて CCR7/DC は CCL21（CCR7 のリガンド）の 濃度に依存した遊走活性の上昇を示したことから， AdRGD-CCR7 を用いた遺伝子導入によって細胞 膜上に発現した CCR7 タンパクは, CCL21 濃度を
感知して DC に遊走刺激を伝える本来の生物活性を 保持したケモカインレセプターであることも判明し た (Fig. 11(A))。さらに, EGFPトランスジェニ ックマウス由来の DC から調製した CCR7/DC を 野生型マウスの側腹部皮内に投与し，48 時間後に おける所属リンパ節（鼠径部リンパ節）への集積性 を flow cytometry 解析で検討したところ， CCR7/ $\mathrm{DC}$ 投与群ではコントロール DC を投与した群と比 較して 5-15 倍高いリンパ節への DC 集積が認めら れた（Fig. 11(B))。これらの結果は, AdRGD シ ステムを応用した DCへのケモカインレセプター遺 
(A)

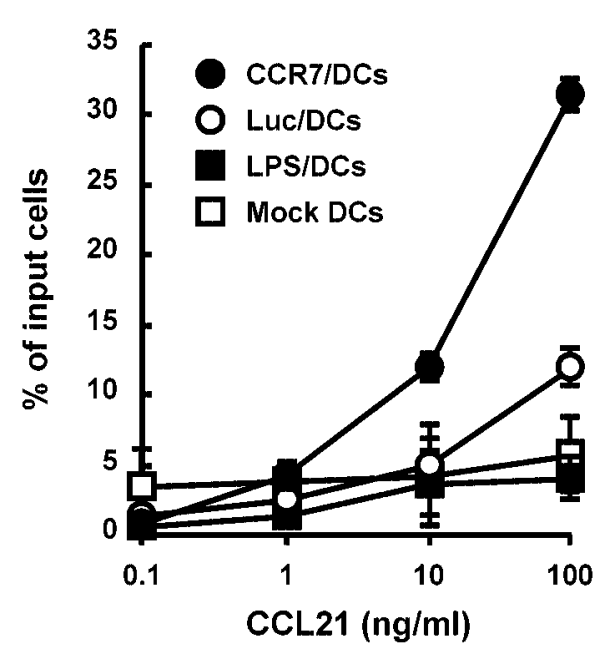

(B)

$\left(\times 10^{3}\right)$

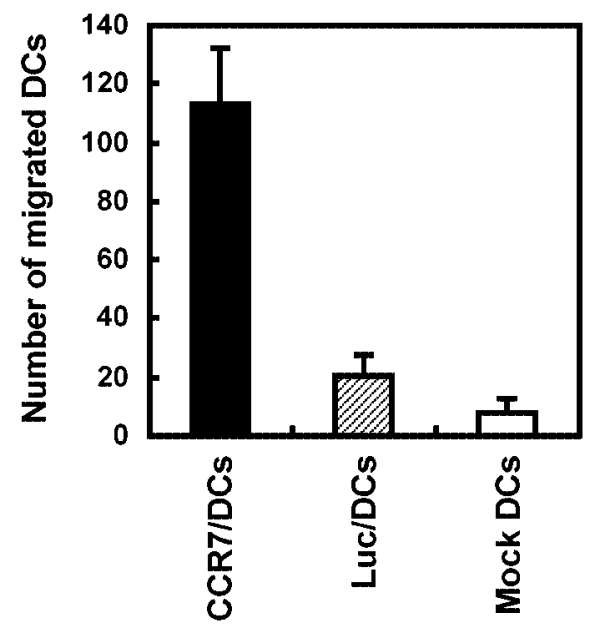

Fig. 11. In vitro Chemotaxis (A) and In vivo Migration (B) of CCR7/DCs

(A) : In vitro chemotaxis assay was performed by a Chemotaxicell-24 installed on 24-well culture plate. CCL21 solution was added in the lower compartment at the indicated concentration, and CCR7/DCs transduced with AdRGD-CCR7 at 50 MOI, Luc/DCs transduced with AdRGD-Luc (control vector) at 50 MOI, LPS $/$ DCs stimulated with $1 \mu \mathrm{g} / \mathrm{ml}$ lipopolysaccharide, or mock DCs were placed in the upper chamber at $10^{6}$ cells. After 4 h-incubation, the number of cells that migrated to the lower compartment was counted. The chemotactic activity was expressed in terms of the percentage of the input cells calculated by the following formula: $(\%$ of input cells $)=($ the number of migrated cells $) /\left(\right.$ the number of cells placed in Chemotaxicell-24; $10^{6}$ cells $) \times 100$. (B) : DCs derived from EGFPtransgenic mice were transduced with AdRGD-CCR7 or AdRGD-Luc at $50 \mathrm{MOI}$, and then were intradermally injected into the left flank of C57BL/6 mice at $2 \times$ $10^{6}$ cells $/ 50 \mu$ l. Two days later, the draining inguinal lymph nodes were collected from these mice, and a single cell suspension was prepared. The abundance of EGFP-positive DCs was assessed by flow cytometric analysis acquiring 500000 events. The number of DCs that had migrated into draining lymph nodes was calculated by multiplying the EGFP-positive DC-frequency by the total number of isolated lymph node cells.

伝子の導入によって，DCのケモカイン応答性並び に生体に投与した際の体内挙動を改変できることを 示している. また，CCR7/DC が in vivoにおいて 非常に優れたリンパ組織移行能を発揮するワクチン 担体であることを示唆しており，これはDC 免疫療 法における効率のよい免疫エフェクター細胞の活性 化と全身への迅速なエフェクター細胞の供給という 面で非常に優れた利点になると考えられた.

4-2. リンパ組織指向性 DC ワクチンの癌免疫療 法への応用 CCR7/DCの優れたリンパ組織集積 性と DC 免疫療法の有効性改善との関連性を検討す るために, gp100 遺伝子と CCR7 遺伝子とを共導入 した DC（gp100+CCR7/DC）を調製し，B16BL6 腫瘍モデルにおけるワクチン機能を解析した（Fig. 12). ${ }^{32)}$ Mock DC あるいは CCR7/DC を免疫投与し た群と比較して, gp100 遺伝子のみを導入した DC (gp100/DC) を投与したマウスにおいては Fig. 8 と同様に攻撃接種した B16BL6 腫瘍の顕著な増殖 遅延が誘導された。またその抗腫瘍効果は，ワクチ ン接種する gp $100 / \mathrm{DC}$ 数に依存して増大した。一 方， gp100+CCR7/DCを $2 \times 10^{5}$ cells $/$ mouse で免
疫した群においては， $5 \times 10^{5}$ の gp100/DC を免疫 したマウスと同等の抗腫瘍効果が観察され，さらに $5 \times 10^{5}$ cells/mouse での gp $100+$ CCR7/DC ワクチ ン投与は，より強力に B16BL6 腫瘍の増殖を抑制 することができた。 また，これらの遺伝子導入 DC を投与したマウスにおける CTL 活性を Eu-release assay により比較したところ，B16BL6 攻撃接種に 対するワクチン効果の結果を反映して, gp100+ CCR7/DC を投与したマウスの脾細胞中には gp 100 /DC 投与群を上回る B16BL6 特異的傷害活性が検 出された。したがって，DC 免疫療法に TAA 遺伝 子と CCR7 遺伝子を共導入した DC を応用するこ とで, 従来の $\mathrm{TAA}$ 遺伝子のみを導入した DC の適 用と比較して，より少ない投与細胞数で効果的な腫 瘍免疫を誘導できることが示された.

本成果は，積極的なリンパ組織移行能を付与した CCR7/DC ワクチンの DC 免疫療法への応用が，有 効な治療効果を達成するために必要とされていた DC 投与量を大幅に低減できることを示しており， (1)DC 前駆細胞単離のために必要な患者の採血負担 の軽減，(2)DCワクチン調製における労力・コスト 


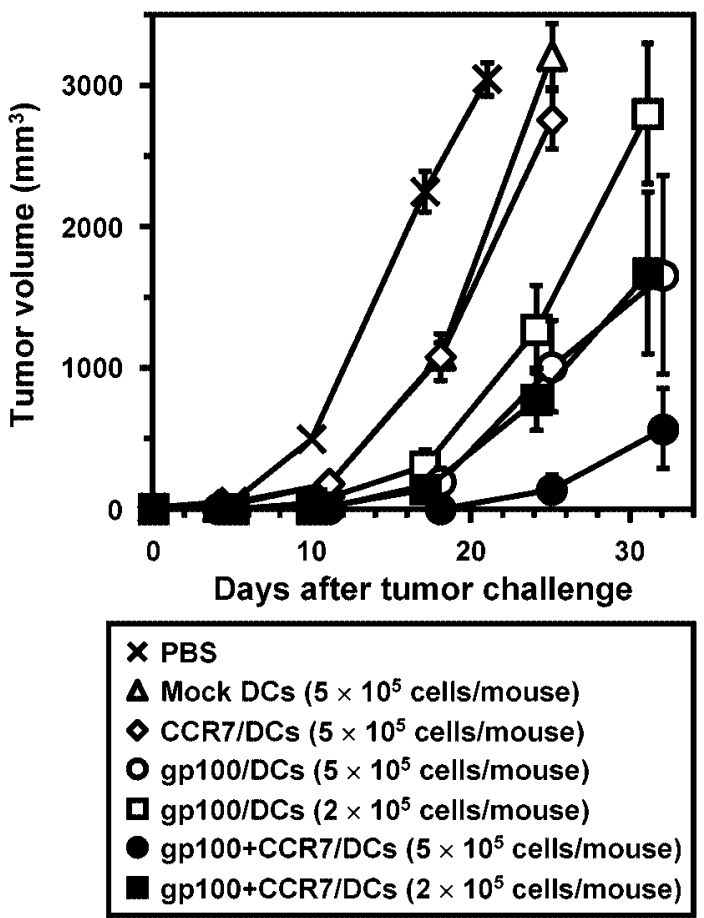

Fig. 12. Vaccine Efficacy of DCs Co-transduced with CCR7 and gp100 Gene against B16BL6 Melanoma Challenge CCR7/DCs, gp100/DCs, and gp100+CCR7/DCs were prepared using corresponding AdRGD vectors at $25 \mathrm{MOI}$, and then cultured for $24 \mathrm{~h}$. C57BL/6 mice were immunized by intradermal injection of transduced DCs or mock DCs into the left flank at the indicated cell dosage, and then $4 \times 10$ B16BL6 cells were inoculated into the right flank of the mice at 1 week postvaccination. The tumor volume was assessed as described in Fig. 8 legend.

の削減，という観点から DC 免疫療法の臨床応用実 現に大いに貢献するものと期待される.

\section{5. おわりに}

筆者らが推進する細胞性製剤に関する研究は，細 胞が生体のホメオスタシスを維持するために営んで いる生命現象に学び，その生命現象を応用して臨床 応用可能な細胞療法を開発しようとするものであ り，これは病態改善・治癒を目的とした従来の輸血 や臓器移植の概念・方法論を薬物治療やワクチン療 法の分野へと応用・進化させたものである，米国 Drug \& Market Development Publications による市 場調査では，最近の幹細胞技術の進展やヒト ES 細 胞の確立を受けて, 細胞療法の市場が 2010 年まで に 300 億ドル規模に達すると試算されている．また 数多くのベンチャー企業が細胞療法の開発に参入し ており，近未来的に細胞を“薬”として捉える医療 システムが実現することに大きな期待が寄せられて いる. しかし，細胞療法はいまだ開発途上の技術で あり，有効性並びに安全性を保証するためには乗り
越えなければならないハードルがいくつも残されて いる. 目的作用を増強した機能性細胞の創製と，こ れら機能性細胞を“細胞性製剂”として目的の作用 部位へ送達するための“Cell Delivery System”の開 発が，より確かな細胞療法を実現するための一助と なることを期待する。

謝辞本研究を遂行するにあたり，御懇篤なる 御指導，御鞭撻を賜りました恩師真弓忠範先生（神 戸学院大学長・大阪大学名誉教授）に心から感謝申 し上げます。また有益な御助言及び多大な御支援を 賜りました山本 昌先生（京都薬科大学薬剤学教室 教授）並びに藤田卓也先生（京都薬科大学薬剤学教 室助教授）に深謝致します。さらに，中川晋作先生 (大阪大学大学院薬学研究科薬剂学分野教授) 並び に水口裕之先生（医薬基盤研究所基盤研究部遺伝子 導入制御プロジェクトプロジェクトリーダー）を始 めとする共同研究者の先生方, 及び実験に御協力頂 きました大学院生・学生諸氏に厚く御礼申し上げま す.

\section{REFERENCES}

1) Okada N., Miyamoto H., Kaneda Y., Yamamoto Y., Katsume A., Saito H., Yorozu K., Ueda O., Tsutsumi Y., Nakagawa S., Ohsugi Y., Mayumi T., J. Control Release, 44, 195-200 (1997).

2) Okada N., Miyamoto H., Yoshioka T., Katsume A., Saito H., Yorozu K., Ueda O., Itoh N., Mizuguchi H., Nakagawa S., Ohsugi Y., Mayumi T., Biochim. Biophys. Acta, 1360, 53 -63 (1997).

3) Okada N., Miyamoto H., Yoshioka T., Katsume A., Saito H., Yorozu K., Ueda O., Nakagawa S., Ohsugi Y., Mayumi T., Biol. Pharm. Bull., 20, 255-258 (1997).

4) Okada N., Miyamoto H., Yoshioka T., Sakamoto K., Nakagawa S., Mayumi T., Biochem. Biophys. Res. Commun., 230, 524527 (1997).

5) Miyamoto H., Okada N., Yoshioka T., Suzuki R., Sakamoto K., Katsume A., Saito H., Tsutsumi Y., Kubo K., Nakagawa S., Ohsugi Y., Mayumi T., Biol. Pharm. Bull., 22, 295-297 (1999) .

6) Suzuki R., Okada N., Miyamoto H., Yoshio- 
ka T., Sakamoto K., Oka H., Tsutsumi Y., Nakagawa S., Miyazaki J., Mayumi T., Life Sci., 71, 1717-1729 (2002).

7) Suzuki R., Yoshioka Y., Kitano E., Yoshioka T., Oka H., Okamoto T., Okada N., Tsutsumi Y., Nakagawa S., Miyazaki J., Kitamura H., Mayumi T., Cell Transplant., 11, 787-798 (2002).

8) Yoshioka Y., Suzuki R., Oka H., Okada N., Okamoto T., Yoshioka T., Mukai Y., Shibata H., Tsutsumi Y., Nakagawa S., Miyazaki J., Mayumi T., Biochem. Biophys. Res. Commun., 305, 353-358 (2003).

9) Yoshioka Y., Suzuki R., Okamoto T., Okada N., Mukai Y., Shibata H., Tsutsumi Y., Dohi N., Okada N., Nakagawa S., Mayumi T., Biochim. Biophys. Acta, 1624, 54-59 (2003).

10) Mizuguchi H., Nakagawa T., Nakanishi M., Imazu S., Nakagawa S., Mayumi T., Biochem. Biophys. Res. Commun., 218, 402407 (1996).

11) Mizuguchi H., Nakanishi M., Nakanishi T., Nakagawa T., Nakagawa S., Mayumi T., Br. J. Cancer, 73, 472-476 (1996) .

12) Mizuguchi H., Nakagawa T., Toyosawa S., Nakanishi M., Imazu S., Nakanishi T., Tsutsumi Y., Nakagawa S., Hayakawa T., Ijuhin N., Mayumi T., Cancer Res., 58, 5725-5730 (1998).

13) Nakagawa S., Mayumi T., Drug Metab. Pharmacokinet., 18, 223-229 (2003).

14) Kunisawa J., Masuda T., Katayama K., Yoshikawa T., Tsutsumi Y., Akashi M., Mayumi T., Nakagawa S., J. Control Release (in press).

15) Banchereau J., Steinman R. M., Nature, 392, 245-252 (1998).

16) Mellman I., Steinman R. M., Cell, 106, 255258 (2001).

17) Esche C., Shurin M. R., Lotze M. T., Curr. Opin. Mol. Ther., 1, 72-81 (1999).

18) Arthur J. F., Butterfield L. H., Roth M. D., Bui L. A., Kiertscher S. M., Lau R., Dubinett S., Glaspy J., McBride W. H., Economou J. S., Cancer Gene Ther., 4, 17-25 (1997).

19) Okada N., Saito T., Mori K., Masunaga Y., Fujii Y., Fujita J., Fujimoto K., Nakanishi T., Tanaka K., Nakagawa S., Mayumi T., Fujita T., Yamamoto A., Biochim. Biophys. Acta,
1527, 97-101 (2001)

20) Okada N., Tsujino M., Hagiwara Y., Tada A., Tamura Y., Mori K., Saito T., Nakagawa S., Mayumi T., Fujita T., Yamamoto A., Br. J. Cancer, 84, 1564-1570 (2001).

21) Okada N., Tsukada Y., Nakagawa S., Mizuguchi H., Mori K., Saito T., Fujita T., Yamamoto A., Hayakawa T., Mayumi T., Biochem. Biophys. Res. Commun., 282, 173179 (2001).

22) Okada N., Masunaga Y., Okada Y., Iiyama S., Mori N., Tsuda T., Matsubara A., Mizuguchi H., Hayakawa T., Fujita T., Yamamoto A., Cancer Gene Ther., 10, 421431 (2003).

23) Bergelson J. M., Cunningham J. A., Droguett G., Kurt-Jones E. A., Krithivas A., Hong J. S., Horwitz M. S., Crowell R. L., Finberg R. W., Science, 275, 1320-1323 (1997).

24) Wickham T. J., Mathias P., Cheresh D. A., Nemerow G. R., Cell, 73, 309-319 (1993).

25) Mizuguchi H., Kay M. A., Hum. Gene Ther., 9, 2577-2583 (1998)

26) Mizuguchi H., Kay M. A., Hum. Gene Ther., 10, 2013-2017 (1999).

27) Mizuguchi H., Koizumi N., Hosono T., Utoguchi N., Watanabe Y., Kay M. A., Hayakawa T., Gene Ther., 8, 730-735 (2001).

28) Okada Y., Okada N., Nakagawa S., Mizuguchi H., Takahashi K., Mizuno N., Fujita T., Yamamoto A., Hayakawa T., Mayumi T., Jpn. J. Cancer Res., 93, 436-444 (2002).

29) Okada N., Saito T., Masunaga Y., Tsukada Y., Nakagawa S., Mizuguchi H., Mori K., Okada Y., Fujita T., Hayakawa T., Mayumi T., Yamamoto A., Cancer Res., 61, 79137919 (2001).

30) Okada N., Masunaga Y., Okada Y., Mizuguchi H., Iiyama S., Mori N., Sasaki A., Nakagawa S., Mayumi T., Hayakawa T., Fujita T., Yamamoto A., Gene Ther., 10, 18911902 (2003).

31) Okada N., Iiyama S., Okada Y., Mizuguchi H., Hayakawa T., Nakagawa S., Mayumi T., Fujita T., Yamamoto A., Cancer Gene Ther., 12, 72-83 (2005)

32) Okada N., Mori N., Koretomo R., Okada Y., Nakayama T., Yoshie O., Mizuguchi H., 
Hayakawa T., Nakagawa S., Mayumi T., Fujita T., Yamamoto A., Gene Ther., 12, 129139 (2005).

33) Yoshie O., Imai T., Nomiyama H., Adv. Immunol., 78, 57-110 (2001).

34) Zlotnik A., Yoshie O., Immunity, 12, 121-127 (2000).

35) Bokoch G. M., Blood, 86, 1649-1660 (1995).

36) Murphy P. M., Annu. Rev. Immunol., 12, 593 -633 (1994).

37) Okada N., Gao J., Sasaki A., Niwa M., Okada Y., Nakayama T., Yoshie O., Mizuguchi H., Hayakawa T., Fujita T., Yamamoto A., Tsutsumi Y., Mayumi T., Nakagawa S., Biochem. Biophys. Res. Commun., 317, 68-76 (2004).

38) Okada N., Sasaki A., Niwa M., Okada Y., Hatanaka Y., Tani Y., Mizuguchi H.,
Nakagawa S., Fujita T., Yamamoto A., (submitted).

39) Kupiec-Weglinski J. W., Austyn J. M., Morris P. J., J. Exp. Med., 167, 632-645 (1988).

40) Lappin M. B., Weiss J. M., Delattre V., Mai B., Dittmar H., Maier C., Manke K., Grabbe S., Martin S., Simon J. C., Immunology, 98, 181-188 (1999).

41) Martin-Fontecha A., Sebastiani S., Hopken U. E., Uguccioni M., Lipp M., Lanzavecchia A., Sallusto F., J. Exp. Med., 198, 615-621 (2003).

42) Gunn M. D., Kyuma S., Tam C., Kakiuchi T., Matsuzawa A., Williams L. T., Nakano H., $J$. Exp. Med., 189, 447-450 (1999) .

43) Förster R., Schubel A., Breitfeld D., Kremmer E., Renner-Meller I., Wolf E., Lipp M., Cell, 99, 23-33 (1999). 